\title{
The circular economy concept in the municipal wastewater and sewage sludge management - site-specific cases from Poland
}

Małgorzata Jadwiga Kacprzak ( $\sim$ malgorzata.kacprzak@pcz.pl )

Częstochowa University of Technology https://orcid.org/0000-0002-3897-8659

\section{Research Article}

Keywords: water cycle, wastewater treatment, circular economy, bio-waste management, biogas, energy self-sufficiency, Poland

Posted Date: February 15th, 2021

DOl: https://doi.org/10.21203/rs.3.rs-190616/v1

License: @ (i) This work is licensed under a Creative Commons Attribution 4.0 International License. Read Full License

Version of Record: A version of this preprint was published at Clean Technologies and Environmental Policy on August 4th, 2021. See the published version at https://doi.org/10.1007/s10098-021-02178-w. 


\section{Abstract}

Introduction of the circular economy package as a result of the necessity to protect natural resources has also forced a new approach for effective wastewater and biowaste treatment and management. Wastewater treatment plants (WWTPs) have become crucial elements of regional bioeconomy - mainly through energy (waste to energy) and matter (nutrients-energy-water) recovery as an element of sustainable development of a smart city. In Poland in 2019 operated 3278 municipal wastewater treatment plants. To achieve specific effluent goals for BOD, nitrogen and phosphorus, different adaptations and modifications have been made. Modernization of technological lines of wastewater treatment has led to a significant improvement in the quality of treated sewage, at the largest WWTPs in Warsaw, Cracow or Gdansk. Eleven WWTPs produce approx. $34 \%$ of the total volume of approx. $337 \mathrm{GWh}$ of electricity from biogas in Poland. The potential of producing electricity from biogas in WWTPs in Poland can be estimated at approx. $700-850 \mathrm{GWh}$ per year. According to the data of the Statistics Poland in 2019 in Poland approx. 25\% of sewage sludge was used directly in agriculture and for land reclamation. Simultaneously more than 100 WWTPs produce compost at high quality. However only few produce organic/organic-mineral fertilizers, mainly with addition of calcium.

\section{Introduction}

In December 2015, the European Commission announced a communication (EU 2015) to the European Parliament, the Council, the European Economic and Social Committee and the Committee of the Regions, which sets out new directions for a major transformation of the European economy. The Circular Economy Package aims to harmonise various waste directives and will contain new targets for the increased recycling of waste (EC, 2015).

The "Closing the loop - an EU action plan for the circular economy" indicated a departure from the traditional linear economy model based on obtaining raw materials, production, use and waste disposal. In the new model, the value of products, materials and resources is retained for as long as possible. On 4 March 2019, the European Commission adopted a comprehensive report on the implementation of the Circular Economy Action Plan. The main achievements under the Action Plan are presented in the report, and it sketches out future challenges towards a climate-neutral, circular economy where pressure on natural and freshwater resources as well as ecosystems is minimized. However, it is common knowledge that these assumptions can be introduced only sequentially, forcing industrial symbiosis and the following innovation, resulting from the need to create new technological solutions, measurement methods or devices. One of the service facilities in which the "circular economy" model assumptions can be successfully implemented is the water and sewage industry. New CE model framework in the water and wastewater sector, which includes the six following actions: reduction-prevent wastewater generation by the reduction of water usage and pollution reduction at source; reclamation (removal)-an application of effective technologies for the removal of pollutants from water and wastewater; reuse-reuse of wastewater as an alternative source of water supply (non-potable usage), recycling-recovery of water from wastewater for potable usage; recovery-recovery of resources such as nutrients and energy from water-based waste, and rethink-rethinking how to use resources to create a sustainable economy, which is ee of waste and emissions (Smol et al. 2020). The new Regulation (EU) 2020/741 on minimum requirements for water reuse for agricultural irrigation of 25 May 2020 will apply from 26 June 2023 and are expected to stimulate and facilitate water reuse in the EU, however under strict circumstances for water quality requirements. Nowadays, WWTP managers can reuse the treated effluent in the system, contributing to the closure of the water cycle and avoiding pumping the treated water into the sea as for example in Spain (Hagenvoort et al. 2019). On the other hand, the important questions regarding the illegal connection of waste pipes with the traditional irrigation or the payment of pumping costs for reuse have gone unanswered, and there is a need for better reflection from all stakeholders (Hagenvoort et al. 2019). WWTPsPlants very frequently operate within the linear economy with the main target connected with wastewater treatment at the suitable level. Part of them understand necessity to improve energy efficiency, however lack is practical approach and well documented cases in this subject. Currently WWTPs should be an area where these assumptions can be successively implemented through ( Qui et al. 2019, Sfez et al. 2019): i) closed water and wastewater cycles, ii) recovery of valuable substances (N, P, cellulose, humic acids, VFA), iii) recovery of products generated in technological processes, iv) recovery of energy and heat.

The transformation of WWTPs and/or biowaste facilities from "the strategy one goal" (wastewater and waste treatment) in to "the CE strategy" as biorefineries (Tobin et al. 2020), bio-power (Pott et al. 2018) or even biomaterial producers (You et al. 2019) is becoming more realistic nowadays. Kehrein et al. (2020) calculating market supply potentials of water, energy, fertilizer and other products recoverable from municipal WWTPs in the Netherlands or Flanders identified potential resource recovery and market supply potential. They found on the base the data from 11 WWTPs that advanced technologies used for water recovery, such microfiltration and ultrafiltration could reduce Dutch freshwater use by $17 \%$, while reverse osmosis could reduce it by $13 \%$. Despite many existing technologies and strategic documents at EU $(2016,2020)$ or national level, it is difficult to apply these solutions comprehensively in practice, combining wastewater treatment with the production of energy, fertilizers, saving water and reducing the negative impact on the environment at the regional level. Kehrein et al (2020) identified It is also very difficult to predict how European Green Deal dissolve this problem. Actually Commission's work is concerned on evaluation of Sewage Sludge Directive (86/278/EEC). The main benefit of the SSD is its role in the protection of human health and the environment against the harmful effects of contaminated sludge in agriculture. Both European Green Deal and the Circular Economy Action Plan (CEAP) accept as a priority area the importance of recycling of materials, in line with circular economy principles. However in line with the Commission's zero pollution ambition announced in the European Green Deal - it is even more important to avoid pollution of soil, water and/or air. Scientific progress and technological developments as well as changes in the policy landscape resulting from the first and second CEAP, the Bioeconomy Strategy, the new Fertilising Products Regulation, the Farm to Fork Strategy, the EU Biodiversity Strategy for 2030 and the recently evaluated Urban Waste Water Treatment Directive 91/271/EEC (UWWTD) caused that Commission's decided to revise the SSD, as outlined in the New Circular Economy Action Plan adopted on 11 March 2020.

The subject of the presented work is to determine the implementation of circular economy principles in water and sewage management in WWTPs in Poland. The specific case study makes it possible to show in practice the effectiveness of combining different ways of proceeding during wastewater treatment in the context of circular economy.

\section{Statistical Data}


It is estimated that almost $61 \%$ of people in Poland live in cities (the average for Europe is $74.4 \%$ ). According to the Statistics Poland (2020), in 2019 on 3278 municipal wastewater treatment plants (which support 75\% of Polish population), 2055 - with a throughput up to $500 \mathrm{~m}^{3}$ of sewage per day, and another 878 with a throughput between 501 to $5000 \mathrm{~m}^{3}$ per day. This is a total of over $90 \%$ of all municipal sewage treatment plants, but their share in the "production" of treated wastewater is only $19 \%$. In addition, the number of treatment plants in the years 2000-2019 serving cities increased from 801 to 938 , while in the villages, simultaneously, the number of treatment plants increased from 1510 to 1965. The largest percentage of the population using sewage treatment plants was recorded in the province Zachodniopomorskie (83\%), and the lowest in the province Lublin - 58\%. At the same time, almost $95 \%$ of the population uses sewage treatment plants, while in villages it is $44 \%$. It has been estimated that $96.6 \%$ of the urban population have access to the treatment plant in the province Kuyavian-Pomeranian, Podkarpackie and Podlaskie regions; the least - $91 \%$ in Silesia. As for the village population - the highest percentage at $62.1 \%$ in the province Pomeranian, and the least $-22.8 \%$ in Podlaskie region.

The problem accompanying the treatment of industrial and municipal wastewater is the specific waste generated during treatment processes in the form of sewage sludge, which, due to its properties, require appropriate management. The amount of generated sludge is only about $1-3 \%$ of the volume of flowing sewage, yet they can pose a potential threat to the environment in the event of their inappropriate management, as they contain, among others, heavy metals and pathogenic organisms. On the other hand, sewage sludge can be used in practice because it is a rich source of organic matter and biogenic elements. Sewage sludge is used for: agricultural purposes, fertilization of soils and plants as a valuable source of nitrogen and phosphorus, compost production, as well as for the reclamation of degraded lands (Fig. 1).

\section{WASTEWATER TREATMENT PLANT (WWTP) AS AN ELEMENT OF THE “CIRCULAR ECONOMY” CONCEPT}

\section{Protection of natural resources - bio-water, bio-resources, biorecycling - legislative solutions}

The water and sewage sector offer many possibilities for implementing activities based on the closed cycle model - both in unitary and broader terms, assuming inter-branch cooperation. This, however, involves a change in the perception of waste generated during wastewater treatment processes and the creation of clear definitions and legislation allowing for multi-directional development in this area of the management. Until recently, wastewater treatment plants were associated with only one task (bringing contaminated sewage to such a quality that they could be safely discharged into the environment). At present, the wastewater treatment plant represents not only a conventional bioprocessing facility, but more often becomes a bio-energy plant (biogas production) or even biorefinery (Gherghel et al. 2019). In theory, many strategies/technologies being proposed for improving energy self-sufficiency at wastewater treatment plants (WWTPs), however limited case studies have been reported. In many WWTPs, an equal priority is the waste to energy (WtE) approach that uses the potential of sewage sludge (but also other organic waste) to generate energy, as well as the new nutrient-energy water paradigm (NEW), (Fig. 2). Both define the future role of WWTPs and its share in creating the national concept of the/a circular economy in relation to municipal infrastructure (Karlo and Gieleciak 2018).

EU legislation should be followed by regulation at the national level. Polish "Strategy for dealing with municipal sewage sludge for 2019-2022" (Ministry of Environment, Poland, 2018) in order to ensure a proper method of dealing with municipal sewage sludge assumes the following strategic objectives:

1) Prevention and reduction of the amount of sewage sludge produced in municipal wastewater treatment plants and elimination of municipal sewage sludge production constituting waste, (which cause problems due to quality) with their management in accordance with regulations, through thermal transformation, application on the surface of the land, fertilizer production, plant suppliers or other.

2) Increasing the amount of municipal sewage sludge treated before entering the environment and increasing the amount of municipal sewage sludge thermally treated.

3) Striving to maximize the degree of use of biogenic substances contained in sewage sludge while meeting all requirements regarding sanitary, chemical and environmental safety.

These regulations are not enough to achieve the circular model of WWTP in the area of waste management, however it can be the starting point for further entries. Generally for planning innovative technologies for wastewater treatment plants in the area of: (i) management of treated wastewater (water renewal and reuse), (ii) reduction of the loss of nutrients and decrease contamination of aquatic environments (removal and recovery of nutrients). Generally considering market potentials, technological innovations, early in the planning and process design phase, may facilitate the design, among others:

- improving the quality and conditions of the water and soil environment by removing harmful micropollutants as well as removing and recovering nutrients

- reducing the consumption of water resources by water reuse

- improving the living conditions of the society in connection with the developed water and sewage management system

- reduction in the extraction of minerals used in the production of mineral fertilizers used in agriculture

- reducing the nuisance of the sewage treatment plant to its immediate surroundings (reduction of odor emissions)

- low construction and operation costs of new and modernized wastewater treatment plants through, inter alia, increasing energy self-sufficiency Area of technology

There are several new technologies, especially used in the operation of wastewater treatment plants, which have been implemented for last years in accordance with the "smart" idea and CE. The following directions of development of technology for the operation of WWTP's in Poland has been developed (Rybicki, 2019):

Loading [MathJax]/jax/output/CommonHTML/jax.js 
- increasing the technological and functional efficiency of the WWTPs based on multi-phase biological reactors for the integrated removal of carbon, nitrogen and phosphorus compounds, and in justified cases, the development of technology to the water resue in accordance with appropriate quality standards;

- implementation of technical solutions ensuring low energy consumption, not only by using devices with low electricity consumption (e.g. blowers, pumps, mixers) but - above all - activities focused on the recovery of some energy in the technological process so as to use it as renewable. First of all, it is the combined production of electricity and heat with the use of fermentation gas generated during the anaerobic treatment of sewage sludge, it can also be the use of heat pumps using sewage as the so-called the lower source. Finally, there are some examples of the use of large, woodless land occupied by wastewater treatment plants as an area for solar farms;

- an example of the application of a technology that significantly reduces electricity consumption is the introduction of nitrogen removal by nitrification instead of the much more energy-consuming denitrification;

- minimization of the volume of sludge after the end of the technological process and the possibility of their disposal / use - to minimize the negative impact on the environment ("ecological footprint") and the use of such methods of sludge treatment, which are characterized by lower electricity consumption than traditional methods.

\section{Water supply potential}

The data of the European Commission show that every year in the EU more than 40 billion $\mathrm{m}^{3}$ of sewage is treated, and less than 1 billion $\mathrm{m}^{3}$ is reused. On June 25, 2020, the Regulation of the European Parliament on the minimum requirements for water reuse entered into force, which included provisions on the use of municipal wastewater for irrigation of agricultural land. The new rules will apply from 26 June 2023 and are designed to stimulate and facilitate water reuse in the EU. In spite of the fact that water reuse is mainly a local solution to a local problem, water stress and balance of costs and benefits should be analysed on a national, regional or river basin scale. However, it should be taken into consideration that the sewage (even after treatment) contains many contaminants (emerging contaminants) that are not standardized and may pose a threat to the environment. Hence, it is necessary to use tertiary treatment, which is a final process that improves wastewater quality before it is reused, recycled or discharged. Unfortunately, the process is usually very expensive. An important issue is also social acceptance of wastewater reuse directly from WWTP (Kehrein et al. 2020). According to Wallis-Lage et al. (2015), the water can be reused in: i) agriculture/horticulture such as irrigation of crops (food and non-food), orchards and pastures or aquaculture including algal farming; ii) industry such as cooling water, process water, aggregate washing, concrete making, soil compaction, dust control and/or iii) municipal/landscape uses such as irrigation of public parks, recreational and sporting facilities, private gardens, roadsides, street cleaning, fire protection systems, vehicle washing, toilet flushing. In the document, several environmental, economic and social benefits are shown. Kehrein et al. (2020) estimated that wastewater discharged by Dutch WWTPs account only $20 \%$ of the total amount of fresh water abstracted in the Netherlands. Generally authors calculate that application of filtration technology, such microfiltration and utrafiltration to wastewater entails a loss of water by $17 \%$ and reverse osmosis by $13 \%$. They are more sceptic in relation to use of advanced treatment of wastewater to obtain the water at good quality to drink. In their opinion only latter technology could reclaim water of high enough quality to enter the potable supply. In Poland a good example is the use of approx. 1.5 million $\mathrm{m}^{3}$ of sewage treated from the "Dabrowka Mala" WWTP operated by Katowickie Wodociągi S.A. by the neighboring heat and power plant belonging to Tauron Heat Sp. z o.o. - Katowice Production Plant. It has been calculated that during the 20 years of operation of the installation, it allowed to save about 30 million $\mathrm{m}^{3}$ of drinking water (Konopka 2019). On the other hand, the Chrzanow Trzebinia Group WWTP has installation for the sewage sludge dewatering process, and in 2019 it launched a "technological water" network pumping treated sewage for the operation of the grate building, to a screenings washer and directly to a sand separator with a sand washer. In addition, treated wastewater will be used not only to rinse the tanks, but also to power specialized vehicles of the WUKU type, which use them to clean the sewage network (Wyrwik 2020). At the WWTP Tychy, treated wastewater is used as technological water. Recirculant (meeting the necessary parameters) is used, by power generators, a sewage sludge dewatering station, a biogas purification station, and is also used for car washing. This approach resulted in the reduction of tap (drinking) water consumption from 185.5 to 117 thousand $\mathrm{m}^{3}$ per year (Karlo and Gieleciak 2019). In EU countries over 40 billion m3 of sewage is treated every year, however only 964 million m3 of treated wastewater is reused, which is only $2.41 \%$ of the potential stream (Strategy, 2016).

\section{Wastewater treatment efficiency}

High requirements to the degree of wastewater treatment, particularly with regard to the elimination of nitrogen and phosphorus, have far-reaching consequences for the construction and operation of treatment plants and lead to the rapidly growing technological progress, especially in terms of process techniques. This applies to both large and small sewage treatment plants. The largest wastewater treatment plant in Poland "Czajka" in Warsaw was established in 1991, and after the modernization and adaptation of the technology to the applicable regulations in the field of wastewater treatment, it increased its capacity from $240,000 \mathrm{~m}^{3} /$ day to $435,300 \mathrm{~m}^{3} /$ day. The sewage treatment plant uses a conventional system to wastewater treatment. The first stage of wastewater treatment is mechanical treatment. Wastewater is transferred to the grates, then to sand traps and preliminary settling tanks. In the second stage, they are directed to the activated sludge reactors with an enhanced biogen (N, P) removal system (Fig. 3). The sewage from the reactors goes to final clarifier, where the activated sludge is separated from the sewage, which is then discharged to the Vistula river.

WWTP has 10 BIODENIPHO technological lines. Each of the technological line is equipped with one biological reactor with Bio-P systems for phosphorus removal, Biodenitro for nitrogen removal, two aeration chambers, two final clarifiers and an activated sludge recirculation system. The efficiency of "Czajka" wastewater treatment system is presented in Table 1 to comparison with data from other WWTPs located in biggest Polish cities. 
Table 1

The comparison in wastewater treatment efficiency from different Polish cities - the quality of treated wastewater

\begin{tabular}{|c|c|c|c|c|c|c|c|c|c|}
\hline \multirow[t]{2}{*}{ Parameter } & \multicolumn{2}{|l|}{$\begin{array}{l}\text { WWTP "Czajka” } \\
\text { Warsaw }\end{array}$} & \multicolumn{2}{|c|}{ WWTP "Plaszow" Cracow } & \multicolumn{2}{|c|}{ WWTP “Saur Neptun” Gdansk } & \multirow[t]{2}{*}{$\begin{array}{l}\text { WWTP } \\
\text { "Pomorzany" } \\
\text { Szczecin }\end{array}$} & \multirow[t]{2}{*}{$\begin{array}{l}\text { WWTP } \\
\text { Lodz }\end{array}$} & \multirow[t]{2}{*}{$\begin{array}{l}\text { WWTP } \\
\text { Lublin }\end{array}$} \\
\hline & $\begin{array}{l}\text { Before } \\
\text { modernization }\end{array}$ & $\begin{array}{l}\text { After } \\
\text { modernization }\end{array}$ & $\begin{array}{l}\text { Before } \\
\text { modernization }\end{array}$ & $\begin{array}{l}\text { After } \\
\text { modemization }\end{array}$ & $\begin{array}{l}\text { Before } \\
\text { modernization }\end{array}$ & $\begin{array}{l}\text { After } \\
\text { modernization }\end{array}$ & & & \\
\hline $\begin{array}{l}\mathrm{BOD} \\
\mathrm{mgO}_{2} / \mathrm{dm}^{3}\end{array}$ & 7.2 & 3.3 & 128 & 11.2 & 7.4 & 2.5 & 4.1 & 8.5 & 4.9 \\
\hline $\begin{array}{l}\mathrm{COD} \\
\mathrm{mgO}_{2} / \mathrm{dm}^{3}\end{array}$ & 49 & 34 & 239 & 125 & 39 & 28 & 32 & 51.4 & 27.3 \\
\hline $\begin{array}{l}\text { Total } \\
\text { Suspended } \\
\text { Solids } \\
\mathrm{mg} / \mathrm{dm}^{3}\end{array}$ & 13.4 & 6.1 & 105 & 35 & 19.3 & 5.3 & 6.0 & 15.4 & 6.0 \\
\hline $\begin{array}{l}\text { Ntot. } \\
\mathrm{mgN} / \mathrm{dm}^{3}\end{array}$ & 11.7 & 7.9 & 23.7 & 10 & 26 & 6.8 & 6.8 & 9.86 & 8.4 \\
\hline $\begin{array}{l}\text { Ptot. } \\
\mathrm{mgP} / \mathrm{dm}^{3}\end{array}$ & 0.54 & 0.42 & 3.1 & 1.1 & 0.46 & 0.23 & 0.61 & 0.72 & 0.28 \\
\hline
\end{tabular}

To achieve specific effluent goals for BOD, nitrogen and phosphorus, different adaptations and modifications have been made to the basic activated sludge design. Well known modifications include sequencing batch reactors (SBR), oxidation ditches, deep shafts, extended aeration, moving beds and membrane bioreactors. In WWTP Tychy as part of numerous investments at the WWTP, two independent technological lines for biological wastewater treatment with the removal of biogenic compounds were introduced. First at all, wastewater treatment is realized according to the patented, modern and one of the largest in Poland, C-Tech technology, based on SBR sequential reactors. The second, in the process of purification, uses activated sludge chambers that work according to the technology of integrated, highly effective removal of nitrogen and phosphorus. - modified Johannesburg (JHB) system - the modification consists in the distribution of the inflow to the pre-denitrification chamber (20\%) and the anaerobic chamber (80\%). Recently, Song et al. (2020) developed a JohannesburgSulfur autotrophic denitrification system (JHB-SAD) to treat municipal wastewater. According to authors, the JHB-SAD could achieve the complete nitrogen removal and theoretically, the nitrogen removal efficiency is independent of COD/TN ratio. Moreover, the system achieved the phosphorus removal of above $90 \%$ with dosing of a small amount of sodium acetate (chemical oxygen demand, COD of $40 \mathrm{mg} / \mathrm{L}$ ). At the WWTP Tychy after modernization, a better quality of wastewater was obtained (Fig. 4). The use of the technology C-TECH was more effective in the case of the reduction of COD/BOD - 42/86\% respectively and nitrogen $-51 \%$. However, the removal of phosphorous equal to $90 \%$ was obtained after treatment by JHB technology, the efficiency similar to that indicated in the literature. Installation of both technologies allowed for greater flexibility in conducting the processes.

\section{Biogas - a source of energy for public utilities}

Biogas produced in separate fermentation chambers (digesters) has recently become the most important energy "substrate" for wastewater treatment plants. According to the data of the Statistics Poland in 2019, there were 2,454 wastewater treatment plants in Poland using biological treatment processes and 817 wastewater treatment plants with increased removal of biogens, and therefore that could be producers of treated biogas. The gas is captured and then directed to the purification and desulphurization installation to be sent to the cogeneration system or thermal boilers. In Poland, there are many commercial technological solutions for biogas production on the market, incl. CAMBI, SEEN TECHNOLOGIES, SYMBIONS. It is estimated that from $1 \mathrm{~kg}$ of the removed organic suspension contained in sludge, is possible to obtain from 0.75 to $1.12 \mathrm{~m}^{3}$ of biogas, with the methane production coefficient being from 80 to 377 $\mathrm{m}^{3} / \mathrm{Mg}$ organic dry matter, and the calorific value from 13 to $23 \mathrm{MJ} / \mathrm{m}^{3}$. After applying effective methods of upgrading, this value can be increased to 35.7 $\mathrm{MJ} / \mathrm{m}^{3}$, thus close to that of natural gas. Upgrading of biogas leads to the creation of a fuel with a very high methane content (over $90 \%$ ), the so-called biomethane that can be successfully used for combustion in cogeneration devices. Unfortunately, the high investment costs of building the installation (both the digesters and the biogas refining system) and the common belief that in order for biogas production to be profitable, at least $10-12$ thousand $\mathrm{m}^{3}$ of sewage per day must flow to the treatment plant. Otherwise, the amount of produced methane will reduce the operating costs of WWTP to such an extent that the cost of building an appropriate infrastructure will exceed possible profits, which makes the production of biogas meaningful only in large facilities. Another counter-argument for the construction of such systems in wastewater treatment plants is the fact that only $50 \%$ of the organic substance is biodegradable in anaerobic conditions and no one has any influence on the composition of wastewater, and thus its suitability for methane production (Grosser et al., 2020). Improving the efficiency of high-quality biogas production can be achieved by:

- optimization of fermentation chambers operation;

- initial conditioning of sewage sludge;

- adequate biostimulation (e.g. dosing the chambers with appropriately selected additives (biochar, zeolites, activated carbon) and bioaugmentation (e.g. using modified microorganisms by genetic engineering methods)

- co-fermentation;

- development of new structures for fermentation chambers. 
In turn, Sarpong and Gude (2020) identified following possibilities for enhanced energy recovery: i) by increasing the COD capture in primary treatment to enhance energy production; ii) by replacing activated sludge process with other less energy-intensive biological treatment technologies; and (iii) by increasing energy production from digesting supplementary feedstock in anaerobic codigestion (AD) schemes. All these methods have their own advantages and disadvantages, but they undoubtedly improve the quantity and quality of the biogas produced. It is estimated that the preconditioning alone can increase the value of the biogas production factor in the range of $10-50 \%$. Another solution already used in Polish wastewater treatment plants is co-fermentation. Highenergy waste is used, e.g. from the food and agricultural industry (sugar factories, fish and meat processing, fat plants, distilleries) or selectively collected biodegradable fraction of municipal waste. A good example is the WWTP Tychy, where the surplus of electricity and heat contributed to the investment in the Water Park Tychy. Co-fermentation is carried out in two separate fermentation chambers with a volume of $5500 \mathrm{~m}^{3}$ each. Mainly biodegradable waste (including waste whey) is used as substrates for co-fermentation, and the continuous optimization of the process has contributed to a gradual increase in the efficiency of biogas production - from almost 2.5 million $\mathrm{m}^{3}$ in 2009 to nearly 6.5 million $\mathrm{m}^{3}$ in 2018 . High energy production the company's own RES (renewable energy source) allowed the Company to leave the standard scope of the company's activity and construction of Water Park Tychy, powered exclusively with energy coming from this source. In order to cover the company's own demand and of the water park, the Tychy wastewater treatment plant has to produce between 16 thousand $\mathrm{m}^{3}$ (in summer) and 19 thousand $\mathrm{m}^{3}$ per day (winter) of biogas. Due to the highly efficient energy economy during codigestion process the average volume of biogas produced in the WWTP Tychy in 2017 was equal 17.4 thousand $\mathrm{m}^{3}$ per day (Karlo and Gieleciak 2019 ). For comparison the WWTP Lodz (the second largest WWTP in Poland) in 2019 produced 23 thousand $\mathrm{m}^{3}$ per day (data from WWTP).

\section{Energy from WWTP}

In WWTP, electricity and / or heat can come from:

- cogeneration and / or biogas combustion systems,

- chemical oxidation of sewage sludge

- thermal treatment of sewage sludge

- heat of treated sewage

- additional installations - ground heat pumps or photovoltaic panels.

Electricity generated by the cogeneration system is used to cover the plant's own needs, and the surplus of electricity is transferred to the public power grid. In the case of a biogas engine, waste heat from the engine cooling system and heat from the exhaust gas system are generated in wastewater treatment plants. This heat is transferred in the engine cooling water stream and used for heating purposes. It is estimated that under Polish conditions the investment costs can pay off even after 9 months.

According to Statistics Poland in 2018, there were approx. $72 \mathrm{MW}$ of electric power using biogas from sewage treatment plants. The above generation capacity allowed to generate approx. $337 \mathrm{GWh}$ of electricity from biogas treated. Data illustrating the scale of electricity production in selected sewage treatment plants in Poland are presented in Table 2. Eleven WWTPs produce approx. 34\% of the total volume of approx. $337 \mathrm{GWh}$ of electricity from biogas in Poland. The potential of producing electricity from biogas in WWTPs in Poland can be estimated at approx. 700-850 GWh per year (Raport, 2020).

Table 2

Average annual energy production form biogas at WWTPs in Poland (Raport, 2020)

\begin{tabular}{|ll|}
\hline WWTP name (city) & Estimated average annual level of electricity production [GWh] \\
\hline Czajka (Warsaw) & 29.6 \\
\hline Lodz & 19.5 \\
\hline Tychy & 14.3 \\
\hline Gdansk-Wschod & 12.7 \\
\hline Poznan - Centralna & 12.0 \\
\hline Hajdow Lublin & 10.0 \\
\hline Poznan - Lewobrzezna & 4.2 \\
\hline Poludnie & 3.6 \\
\hline Pruszkow & 3.5 \\
\hline Krosno & 2.6 \\
\hline Krakow - Plaszow & 1.0 \\
\hline Total & $\mathbf{1 1 3}$ \\
\hline
\end{tabular}

As described Macintosh et al. (2019), Grüneck WWTP operated in Germany increased energy self-sufficiency by $24 \%$ (from 64 to $88 \%$ ) through reducing energy consumption with aeration upgrades ( $8 \%$ increase) and increasing energy production with food waste co-digestion ( $16 \%$ increase). The plant-wide analysis indicated that the aeration upgrades did not affect effluent quality; however co-digesting food waste at $20 \%$ additional organic load caused some minor downstream impacts including reduced dewaterability, fluctuating biogas quality and solids accumulation.

Loading [MathJax]/jax/output/CommonHTML/jax.js 
Dried sewage sludge is also a source of renewable energy and is used, among others in cement plants as alternative fuels. However, according to Cement Producers Association in 2015 the share of sewage sludge in the total amount of alternative fuels used in the technological process (mainly for the production of clinker) was only $0.7 \%$.

\section{Energy self-sufficiency}

Wastewater Treatment Plants is a high energy consuming facility in terms of the necessity for optimizing several technological processes during wastewater as well as sewage sludge treatment. The gain of the balance between the energy, heat production and consumption is one of the most significant challenges posed by the idea of the circular economy. At the WWTP, on the one hand, the energy balance is connected with production of biogas and energy from its own renewable energy source and its quality increase with the usage of the biogas purification station. On the other hand, there is increased energy demand resulting from the need to adapt wastewater treatment processes and sludge treatment to increasingly higher standards for the removal of pollutants. To minimize the need for energy, diagnoses of the most energy-consuming places in technological processes and their modernization or liquidation has been done. Usually the processes used in the third stage of wastewater treatment (UV lamps, ozone generators, pumps etc.) are considered as the most energyconsuming, followed by biological and mechanical treatment. According to Wróblewski and Heidrich (2017), an electricity consumption in the Polish WWTPs ranges from 0.45 to $1.29 \mathrm{kWh} / \mathrm{m}^{3}$, with the average value equal to $0.84 \mathrm{kWh} / \mathrm{m}^{3}$. The similar average values of energy intensity index for WWTPs can be found in the report of the Chamber of Commerce "Polish Water-works" - 0.77kWh/m³ (Benchmarking, 2016) and the study of Gromiec (2016), who makes the need for energy dependency on the size of the treatment plant: $0.84 \mathrm{kWh} / \mathrm{m} 3$ for smaller facilities (less than 100 thousand inhabitants) and $0.62 \mathrm{kWh} / \mathrm{m} 3$ for bigger ones (more than 100 thousand inhabitants). WWTP Tychy produces electricity and heat in the process of cogeneration of biogas produced from the cofermentation of sewage sludge and biodegradable waste, which are obtained from external suppliers from various branches of industry. The approach based on industrial symbiosis has allowed for the achievement of very good energy efficiency indices. Already in 2010, energy produced from biogas covered the demand of the treatment plant up to $99.16 \%$, and since 2012, surpluses have been regularly obtained (Fig. 5). The red line shows that the number of investments in innovative technological solutions and continuous optimization of the cofermentation process have contributed to achieving the energy selfsufficiency of the treatment plant at the level of $200 \%$. Thanks to the energy symbiosis of both facilities, it was possible to entirely cover their demand for electricity and heat from biogas cogeneration arising in a sewage treatment plant, and in addition - surplus energy is sold to the grid (PEC/TAURON), which generates additional profits

Since 2006, when cogeneration units at the WWTP began working, by the end of 2018, 78867.576 MWh of electricity was produced from biogas. To produce an equivalent amount of energy, a conventional power plant would use 37408 tonnes of hard coal. Considering thermal energy generated in cogeneration - the amount of this raw material would increase to 76801 tons (assuming efficiency of the plant at an average level of $33 \%$, heating plant efficiency at an average level of $42 \%$ and a calorific value of coal equal to $23 \mathrm{GJ} / \mathrm{t}$ ). The potential of industrial symbiosis for improve an energy efficiency is not only implementation of co-fermentation (with use of high-energy waste) but also the co-gasification of sewage sludge and municipal waste (including waste biomass classified as other and alternative SRF fuels) with the concept of waste to energy. Moreover the modernization of the most energy-consuming devices and optimalisation some processes also bring significant energy savings. In turn, at the WWTP Klimzowiec (Silesia region) identified the most energy-consuming devices:

- internal recirculation (23.33\%);

- air blowers (20.85\%);

- pump station (10.84\%);

- aeration of biological chambers (9.11\%);

- external recirculation (6.87\%)

- mechanical wastewater treatment (5.86\%).

According to fact that the most energy-consuming process was nitrogen removal (aeration, internal recirculation). Hence, it was decided to change the method of process control (Table 3).

Table 3 Optimalization of nitrogen removal process for energy savings and process efficiency at WWTP Klimzowiec

\begin{tabular}{|ll|}
\hline Before modernization & After modemization \\
\hline aeration control: & aeration control: \\
- to obtain the desired oxygen concentration & - on the concentration of N-NH4 at the outlet of the aeration chambers \\
\hline recirculation control: & recirculation control: \\
- a given percentage of the amount of incoming sewage & - N-NO3 concentration at the outlet of aeration chambers \\
\hline
\end{tabular}

As shown in Table 4 modernization of the most energy-consuming devices did at the WWTP Tychy allow for significant reduction of energy consumption and savings per year. 
Table 4

The changes in energy consumption after modernization of technologies at Tychy WWTP (Gieleciak, 2018)

\begin{tabular}{|c|c|c|}
\hline Innovation & Energy consumption decrease [\%] & Savings per year [MWh] \\
\hline Modernization of the main sewage pumping station & 47 & 241 \\
\hline High-performance interior lighting & 41 & 3 \\
\hline Modernization of aeration of biological chambers & 29 & 1223 \\
\hline Modernization of recirculation the pumping station & 78 & 512 \\
\hline Replacement of lighting fittings for external illumination of the WWTP & 61.5 & 58 \\
\hline
\end{tabular}

On the other hand, not directly related to wastewater treatment/sludge management, but undoubtedly improving the energy efficiency of the company, is to use the existing areas of the sewage treatment plant for the construction of photovoltaic farms. Such a farm was built, among others in sludge lagoons decommissioned at the WWTP in Chrzanow Duzy (Grodzisk Mazowiecki).

\section{Recovery of bio-matter}

Appropriate management of sewage sludge turns out to be important from the point of view of the circular economy, energy management and the depletion of non-renewable resources of minerals from which phosphorus is obtained (apatite, phosphate rock). Sewage sludge is "always" spread over the ground surface. And this is undoubtedly the simplest example of applying the "cradle to cradle" principle. Council Directive 86/278/EEC of 12 June 1986 on the protection of the environment, and in particular of the soil, when sewage sludge is used in agriculture is the one of the oldest European regulation. It prohibits the use of untreated sludge on agricultural land, unless it is injected or placed under the soil surface. Directive also requires that the sludge is applied in a nutrient-sensitive manner and that the quality of the soil, surface and groundwater is not deteriorated. In 2014 , the Directive was assessed as part of the "ex post evaluation of certain waste stream directives". The evaluation revealed a number of shortcomings, largely due to the fact that the regulation was adopted 35 years ago and does not fully meet actual problems connected with presence of new pollutants in environment. In Poland, the use of sewage sludge is regulated by the Regulation of the Minister of the Environment from 2015. According to the data of the Statistics Poland in 2019 in Poland approx. $25 \%$ of sewage sludge is used in agriculture and for land reclamation.

The processing of sludge from waste to product can be difficult - need to make additional installations and many bureaucratic activities. However after reclassification of the waste into a product that can be marketed. From sewage sludge may be produced organic fertilizers, organic-mineral fertilizers or plant growth promoting agents. All of them require certification and fulfillment of the requirements specified in the relevant regulations of the Ministry of Agriculture.

Composting sewage sludge requires mixing them with a structure-forming material, e.g. straw (corn, wheat, from energy crops - miscanthus), sawdust and / or other waste, e.g. grass or organic fraction of municipal waste. However, it should be remembered that the compost remains waste after the process, unless it meets the requirements set out in the Regulation of the Minister of Agriculture and Rural Development of June 18, 2008 on the implementation of certain provisions of the Act on fertilizers and fertilization. The compost produced can be marketed as an organic fertilizer or as an agent supporting the cultivation of plants, in the form of: a soil conditioner (soil improver), a growth stimulant or a cultivation medium. In practice, most often composting facilities or WWTPs apply for the status of an organic fertilizer for nutrient-rich composts or a soil conditioner for other composts. Regardless of the method of bio-matter recovery and inclusion of sewage sludge in the biological cycle, WWTP should choose not only the financial outlay to purchase and implement the appropriate technology, but also R\&D work to obtain the appropriate product quality. It is estimated that in Poland more than 100 WWTPs in Poland produce compost at high quality.

In recent years, sludge treatment methods leading to the production of organic and mineral fertilizers have slowly started to gain importance. On the Polish market can be found, product of the Danish company ORTWED, fertilizer "Biowap" (Decision 91/04; July 13, 2004) OrCal® fertilizer (Decision No. 183/07 Mark HORnn-4077-2 / 07 of 2007); "Gramed" fertilizer with Decision No. 280/11 issued in 2011, "Klonex" fertilizer with Decision No. G-463/14 of 2014; and the "Oskar" fertilizer by OMEGA (Decision 289/12 on February 16, 2012).

In order to produce this type of fertilizers, it is necessary to add a significant amount of inorganic substrates. These are calcium compounds, sulfuric acid, magnesium and potassium compounds, or fly ash from the combustion of hard coal or brown coal.

The most frequently used solutions are based on the introduction of a significant amount of quicklime. (containing active calcium oxide CaO) traditional hygienising agent for sewage sludge:

$\mathrm{CaO}+\mathrm{H}_{2} \mathrm{O} \rightarrow \mathrm{Ca}(\mathrm{OH})_{2}+$ heat

The amount of heat generated by the strong exothermic reaction is directly proportional to the amount of water needed for evaporation and the amount of added quicklime $\mathrm{CaO}$. According to fertilizer manufacturers, the resulting slaked lime can react at a temperature elevated to $135-140{ }^{\circ} \mathrm{C}$ with the presence of, for example, amorphous silicic acid or aluminum compounds present in the sewage sludge.

On June 25, 2019, a new Regulation (EU) 2019/1009 of the European Parliament and of the Council of 5 June 2019 laying down rules on the making available on the market of EU fertilising products and amending Regulations (EC) No 1069/2009 and (EC) No 1107/2009 and repealing Regulation (EC) No 2003/2003 was published. Part II this Regulation prohibits the use of sewage sludge as ingredients in the production of EU fertilizing products. 
According to linear economy - the processing capacity has been the leading factor in the design the wastewater treatment plants as a main value related to the supply and effluent requirements. The CE changed totally approach to WWTP. The facility become a source not anly water but also energy, raw materials or substrates. WWTP, as a Resource Plant, is driven by local conditions and drivers. It should consist of business case philosophy that balances resource supply, sustainable development and financial soundness. The products should be returned at local market (for example heat), regional market (energy, bio-products), national or global market (raw materials). Hence the WWTP as production-site during planning phase of a large-scale renovation or new construction has take into conisderation not only development of technology or social and environmental requirements, but also legislation and economy. Zarei (2020) mentioned that there is many relationships between infrastructures, complex economic-environmental-social-political circumstances and reuse limits. Author identifies different approach: i) best available technology, ii) decission support system, iii) risk management.

There are several steps of a/the decision tree when in combination can result in an optimal model for the circular economy concept. The key points:

- need to recover resources; the necessity of recovering nutrient, water, and energy should be balanced with the cost of technology implementation. Due to the fact that the costs may even make these options non-viable in the short term, it is very important to identify financial limitations versus sustainability goals in the long term;

- resource demands, product necessity should be identified at a local and more general level, its quality, frequency of use, distribution of the end product and storage requirements;

- technology/asset requirements;

- financial factors;

- risk/benefits factors.

Zarei (2020) notes that in the case of recovery of energy from wastewater it could be achieved by some basic actions and system decision tree:

- engaging the public support;

- establishing new policies;

- choosing the most applicable type a wastewater treatment;

- develop a national, regional and local action plan;

- coordinating investments and financing;

- applying the quality criteria to end product;

- evaluating the most cost-effective potential wastewater reuse;

- building suitable infrastructures;

- applying integrated schemes for wastewater treatment and reuse.

Unfortunately, in Poland there are only few WWTPs where the holistic approach to circular economy concept is developing. Good sample is Regional Centre for Water and Wastewater Management Co. in Tychy (RCWWM Tychy, Silesia Region, South Poland) where for many years, has effectively implemented the assumptions of intelligent and sustainable development, being part of the "circular economy" model. RCWWM Tychy as an owner WWTP' has technical and technological facilities for cleaning up over 15 million $\mathrm{m} 3$ of municipal sewage during the year, both from residents and from industrial plants. The company basing on concept three basic pillars - ecology, economics and education improve following rules (Gieleciak, 2018):

- no emission or minimal emission to the environment;

- minimization of waste production;

- energy self-sufficiency;

- rationalization of water usage;

- optimalization of influent and rationalization of technological processes

In this way, the concept of the intelligent (smart) city of SymbioTychy was created by The Centre based on the free flow of energy within the urban framework as an effect of supplying renewable energy from municipal infrastructure and in accordance with the principles of sustainable development (Fig. 5), (Karlo and Gieleciak, 2018) The Centre is one of the first Polish communal companies which introduces elements of a circular economy in a practical way at WWTP optimizing Company's own technological processes and creating a long-term development strategy according to CE.

\section{Conclusion}

The transformation of a linear economy to a circular economy model should be multidirectional, industrialized and organized based on the search for places that are tangible in many areas of the economy and allow for the completion of niches and current needs according to sustainable development. The term "wastewater treatment plant" is associated more with waste disposal and utilization rather than resource opportunities. However, WWTP is slowly becoming an important part of the smart city and change into important producers of water, energy, nutrient and other supplies (metals, humic acids, enzymes, polysaccharides and many others) (Neczaj and Grosser, 2018). Such a model developed at WWTP should reconcile technology requirements, financial factors and risks/benefits which promote all recovery opportunities within the local community. The novelty of such an approach was verified during the introduction of bioeconomy conception into a business model at the facility and shows possible economical, ecological and social benefits. Hence the implementation of the idea, "think globally, do locally" could be a very important point at the trial of introduction of a circular economy at infrastructure of water and wastewater manonamont Tha imnlomantation tho aloh 
entrepreneurs (for supplying high-energy waste to improve methane fermentation efficiency), local government (water park creation and building) and society (conducting educational classes, environmental activities, modernizing the water supply network). The wastewater treatment plant is less of a necessary investment but is usually located on the outskirts of cities due to odor nuisance and the negative impact on the environment.

This determines not only the possibility of using different wastewater treatment technologies, but also ways of managing the biodegradable waste (mainly sewage sludge) arising during the treatment processes. Of course, the question remains open: is it possible to introduce a circular economy model with such a large number and use different technologies of municipal infrastructure facilities?

\section{Declarations}

ACKNOWLEDGMENT: The author thanks for results receiving from Regional Centre for Water and Wastewater Management Co. in Tychy.

The publishing was made possible due to the project financed by the Polish National Agency for Academic Exchange the EnviSafeBioC project - contract No PPI/APM/2018/1/00029/U/001 and the statute subvention of Czestochowa University of Technology, Faculty of Infrastructure and Environment.

\section{References}

Benchmarking (2016) The results of Water and Sewage Enterprises in Poland. Chamber of Commerce "Polish Water”, [in Polish]

Common Implementation Strategy for the Water Framework Directive and the Floods Directive - Guidelines on Integrating Water Reuse into Water Planning and Management in the context of the WFD (2016)

Communication from the Commission to the European Parliament, the Council, the European Economic and Social Committee and the Committee of the Regions "Closing the Loop - an EU action plan for the circular economy. The European Commission, Brussels, (2015)

EU-level instruments on Water Reuse. Final Report to support the Commission's Impact Assessment. Amec Foster Wheeler Environment \& Infrastructure UK Ltd, IEEP, ACTeon, IMDEA and NTUA (2016)

Gherghel A, Teodosiu C, De Gisi S (2019) A review on wastewater sludge valorisation and its challenges in the context of circular economy Journal of Cleaner Production 228: 244-263

Gieleciak Z (2018) Wastewater treatment plant in XXI century as a one of the main elements of bioeconomy concept [in Polish]. ENVICON - XXII International Congress of Environmental Protection. Warsaw, Poland, 2018

Gromiec M (2016) New role of water-sewage management in development of cities and limiting climate change. II Forum of Environmental Protection. Ecology as stimulator of cities development, Warsaw, 15-16.02.2016.

Grosser A, Neczaj E, Jasińska A, Celary P (2020) The influence of grease trap sludge sterilization on the performance of anaerobic co-digestion of sewage sludge. Renewable Energy 161, DOI: 10.1016/j.renene.2020.07.108

Hagenvoort J, Ortega-Reig M, Botella S, García C, de Luis A, Palau-Salvador G (2019) Reusing Treated Waste-Water from a Circular Economy Perspective-The Case of the Real Acequia de Moncada in Valencia (Spain), Water 11, 1830; doi:10.3390/w11091830

Karlo A, Gieleciak Z (2018) Municipal sewage treatment plant as part of circular economy [in Polish]. Gas, Water and Sanitary Technique (5): 178-180

Karlo A. Gieleciak Z. (2019)Energetic symbiosis of wastewater treatment plant and Water Park Tychy as an example of innovative approach of using renewable energy sources [in Polish]. Gas, Water and Sanitary Technique (1):18-21

Kehrein P, van Loosdrecht M, Osseweijer P, Garfí M, Dewulf J, Posada J (2020) A critical review of resource recovery from municipal wastewater treatment plants - market supply potentials, technologies and bottlenecks Environ. Sci.: Water Res. Technol., 6: 877-910

Konopka D (2019) Use of wastewater for cooling heat and power plants [in Polish]. Wodociągi i Kanalizacja 07/08.

Macintosh C, Astals S, Sembera C, Ertl A, Drewes JE, Jensen PD, Koch K (2019) Successful strategies for increasing energy self-sufficiency at Grüneck wastewater treatment plant in Germany by food waste co-digestion and improved aeration Applied Energy 242: 797-808

Neczaj E, Grosser A (2018) Circular Economy in Wastewater Treatment Plant-Challenges and Barriers, Proceedings, 2: 614

Qui J, Wang H, Wang K, Yu G, Ke B, Yu H-Q, Ren H, Zheng X, Li J, Li W-W, Gao S, Gong H (2019) Municipal wastewater treatment in China: Development history and future perspectives. Front. Environ. Sci. Eng., 13(6): 88

Polish Statistical Office, Environment, 2019, Warsaw, 2020

Pott R, Johnstone-Robertson M, Verster B, Rumjeet, S, Nkadimeng L, Raper T, Rademeyer S, Harrison STL (2018) Wastewater Biorefineries: Integrating Water Treatment and Value Recovery, In: Walter Leal Filho and Dinesh Surroop Editors The Nexus: Energy, Environment and Climate Change, Springer International Publishing AG, pp. 289-304

Loading [MathJax]/jax/output/CommonHTML/jax.js 
Report Biogas in Poland 2020, Biomasa (2020)

Rybicki S (2019) New technologies of water and wastewater treatment in relation to the idea of Smart Cities.[in Polish] Wodociagi Polskie 1/53

Sarpong G, Gude VG (2020) Near Future Energy Self-sufcient Wastewater Treatment Schemes. International Journal of Environmental Research https://doi.org/10.1007/s41742-020-00262-5

Sfez S, De Meester S, Vlaeminck SE, Dewulf J (2019) Improving the resource footprint evaluation of products recovered from wastewater: A discussion on appropriate allocation in the context of circular economy. Resources, Conservation \& Recycling 148: 132-144

Smol M, Adam C, Preisner M (2020) Circular economy model framework in the European water and wastewater sector Journal of Material Cycles and Waste Management 22: 682-697 https://doi.org/10.1007/s10163-019-00960-z

Song Y, Li H, Han Y, Lu C, Hou Y, Zhang Y, Guo J (2020) Landfill leachate as an additional substance in the Johannesburg-Sulfur autotrophic denitrification system in the treatment of municipal wastewater with low strength and low COD/TN ratio. Bioresource Technology 295: 122287

Strategy for dealing with municipal sewage sludge for 2019-2022 [in Polish]. Ministry of Environment, Poland, (2018)

Tobin T, Gustafson R, Bura R. et al. (2020) Integration of wastewater treatment into process design of lignocellulosic biorefineries for improved economic viability. Biotechnol Biofuels 13, 24, https://doi.org/10.1186/s13068-020-1657-7

Urban Waste Water Directive Overview. Available online: http://ec.europa.eu/environment/water/waterurbanwaste /index_en.html (accessed on 18 June 2020)

You X, Valderrama C, Cortina JL (2019) Nutrients recovery from treated secondary mainstream in an urban wastewater treatment plant: A financial assessment case study. Science of the Total Environment 656: 902-909

Wallis-Lage CL, Scanlan P, de Barbadillo C, Barnard J, Shaw A, Tarallo S (2015) The Paradigm Shift: Wastewater Plants to Resource Plants, https://www.researchgate.net/publication/272208871 (published 30 June 2015)

Wróblewski J, Heidrich Z (2017) Energy consumption of municipal sewage treatment plants [in Polish] Gaz, Woda i Technika Sanitarna 8: 325-329

Wyrwik S (2020) Wastewater Recycling: Need or Obligation? Wodociagi i Kanalizacja 06.2020

Zarei M (2020) Wastewater resources management for energy recovery from circular economy perspective. Water-Energy Nexus 3: 170-185

\section{Figures}

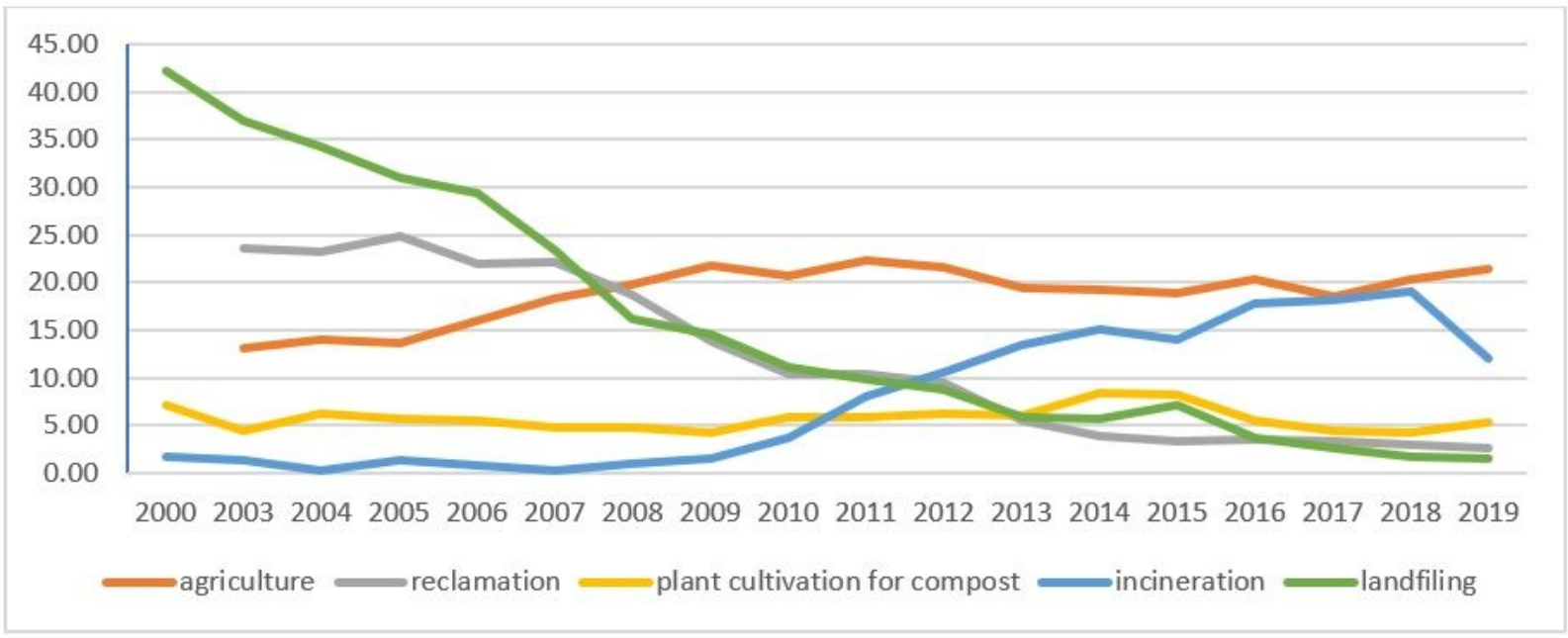

\section{Figure 1}

The sewage sludge management [\%] between year 2000 and 2019 according Statistics Poland data. 


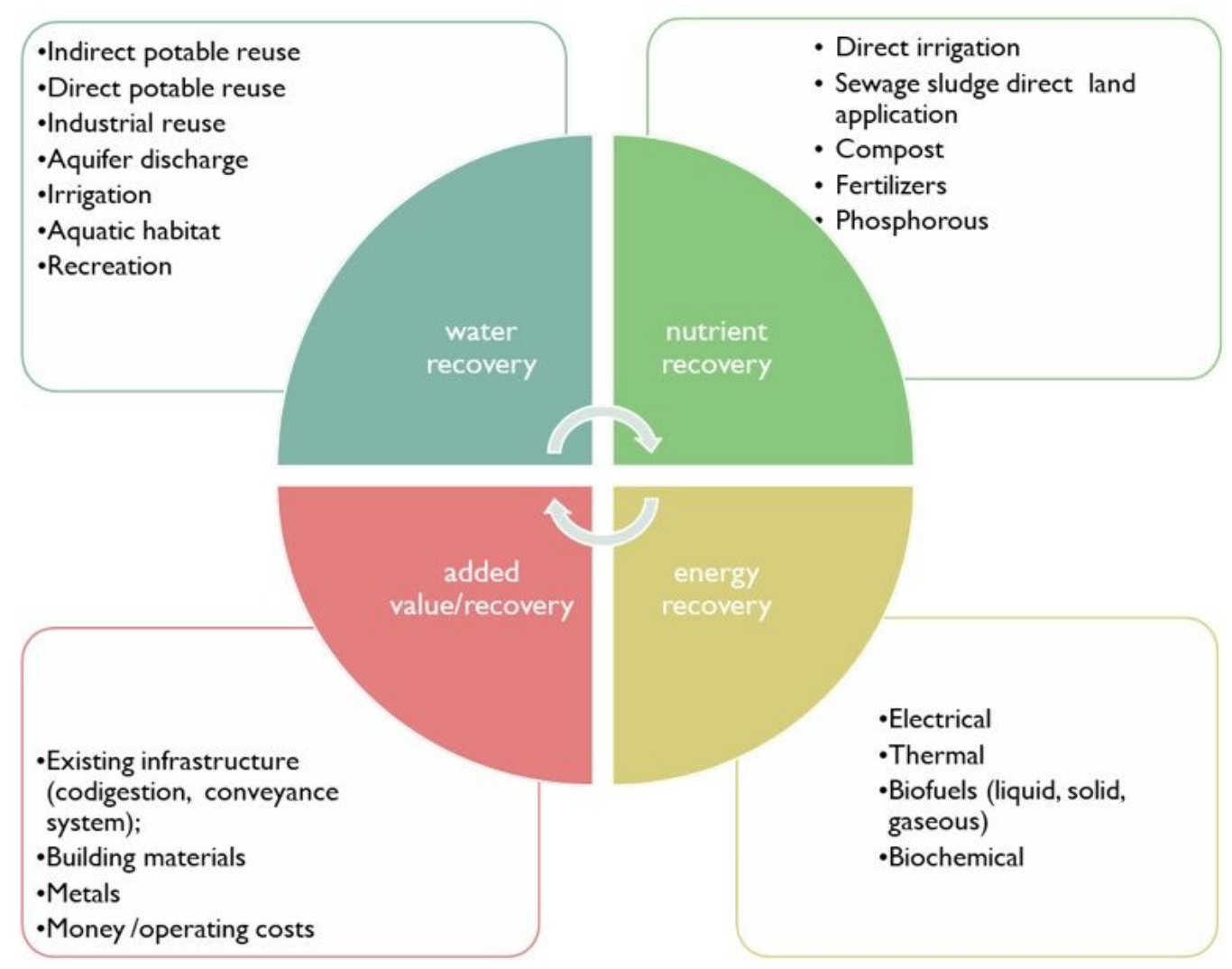

\section{Figure 2}

Resource recovery ways within nutrient-energy water paradigm (NEW), (Wallis-Lage et al. 2015)

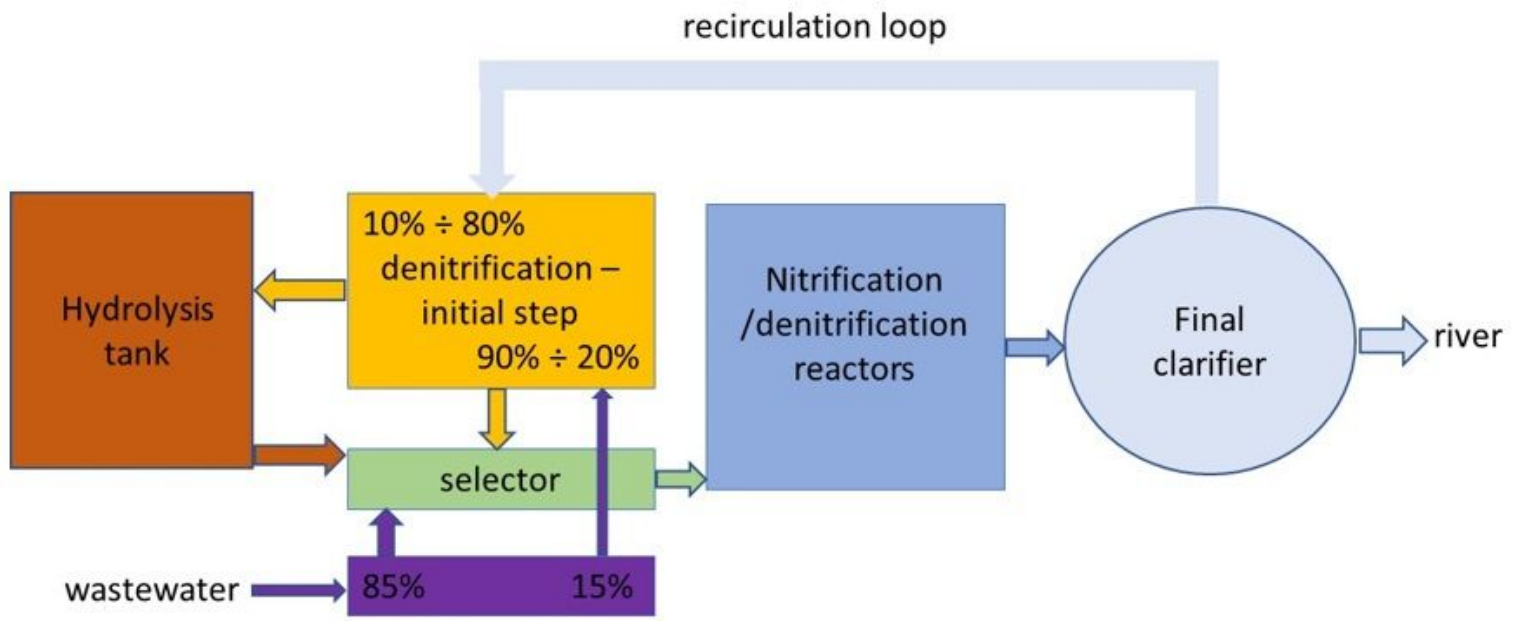

Figure 3

The block diagram of the biological system of the WWTP Czajka, Warsaw (MPWiK, Warsaw) 


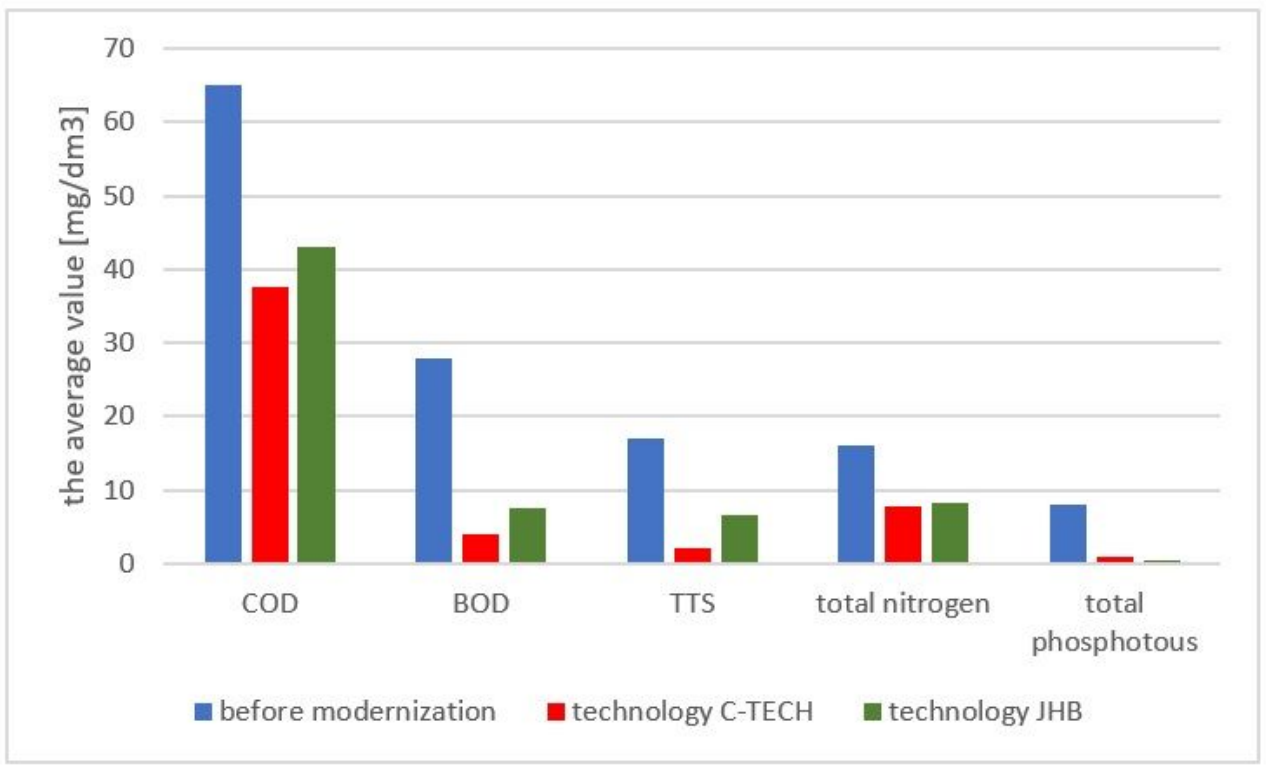

Figure 4

The values of wastewater contamination indicators at WWTP' Tychy before and after modernization with use of technology C-TECH and JHB (COD chemical oxygen demand; BOD - biological oxygen demand, TTS - Total suspended solids (Karlo and Gieleciak 2019)

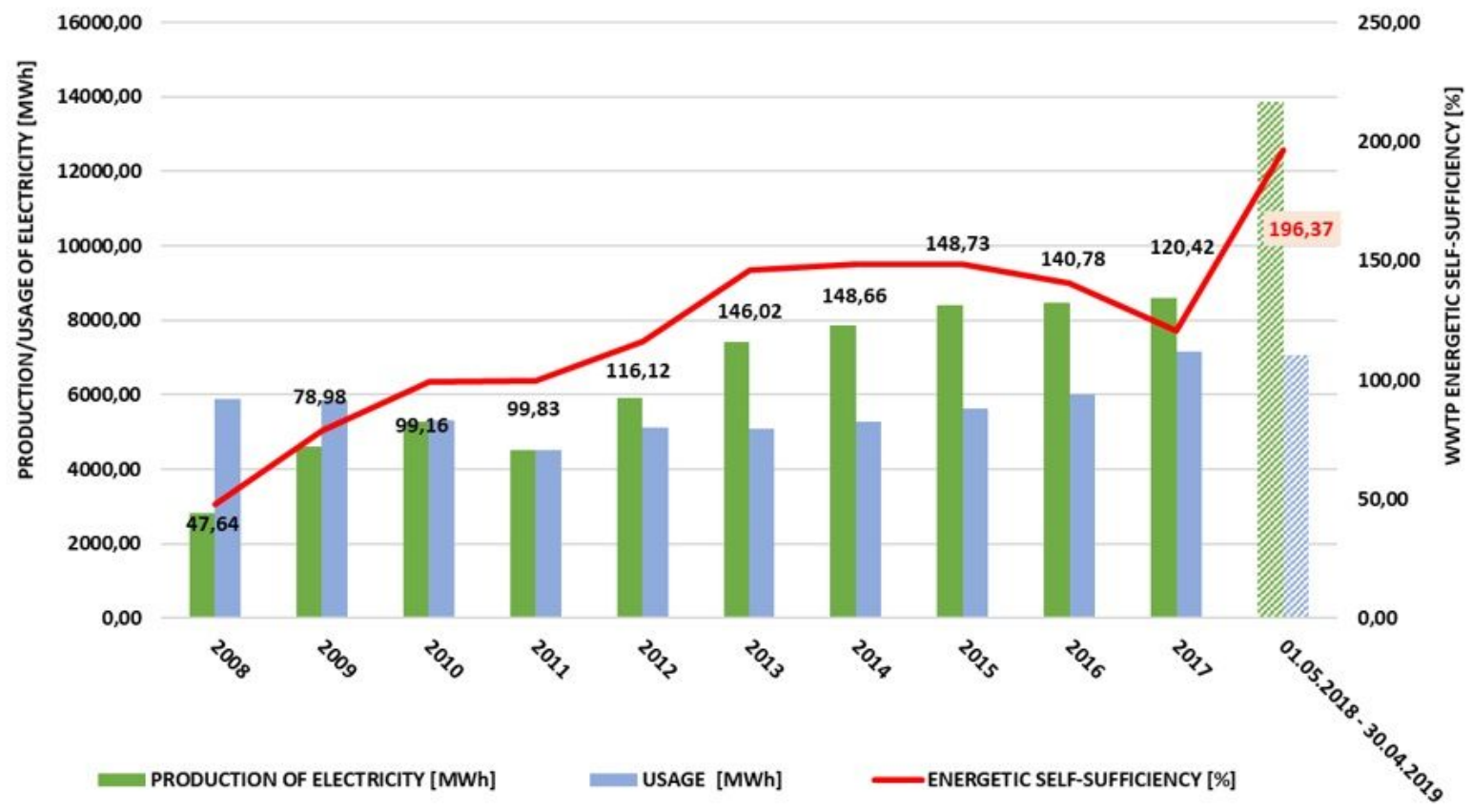

Figure 5

Production/consumption energy in WWTP Tychy - Urbanowice (Karlo and Gieleciak 2019) 


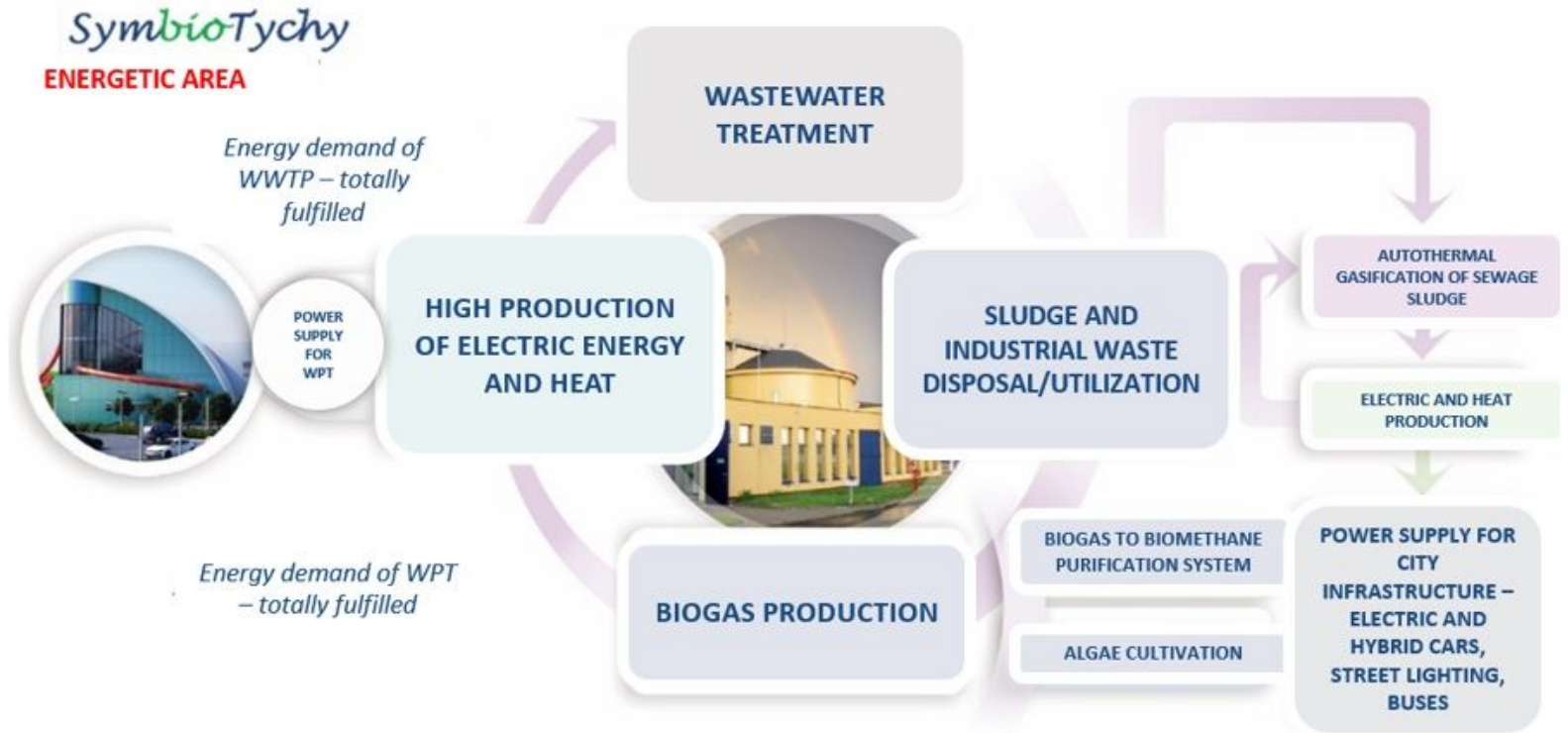

Figure 6

The conception of smart city SymbioTychy - cooperation among wastewater treatment (Karlo and Gieleciak, 2018) 